\section{Organisation for Economic Co-operation and Development (OECD)}

Origin. Founded in 1961 to replace the Organisation for European Economic Co-operation (OEEC), which was established in 1948 and linked to the Marshall Plan. The change of title marks the Organisation's altered status and functions: it ceased to be a European body with the accession of Canada and USA as full members and became a forum of global influence adding development to its list of core priorities. The Organisation aims to promote policies designed to achieve the highest sustainable economic growth and employment, as well as raising standards of living in member countries, while maintaining financial stability, thereby contributing to the development of the world economy; to contribute to sound economic expansion in member as well as non-member economies in the process of economic development; and to contribute to the expansion of world trade on a multilateral, non-discriminatory basis in accordance with international obligations.

Members. Australia, Austria, Belgium, Canada, Czech Republic, Denmark, Finland, France, Germany, Greece, Hungary, Iceland, Ireland, Italy, Japan, South Korea, Luxembourg, Mexico, Netherlands, New Zealand, Norway, Poland, Portugal, Slovakia, Spain, Sweden, Switzerland, Turkey, UK and USA. An accession agreement with Chile was signed in Jan. 2010. It will become a member once parliament ratifies the OECD's convention. Discussions that began in May 2007 on the possible future accession of Estonia, Israel, Russia and Slovenia are ongoing.

Activities. The OECD's main fields of work are: economic policy; statistics; energy; development co-operation; sustainable development; public governance and territorial development; international trade; financial and enterprise affairs; tax policy and administration; food, agriculture and fisheries; environment; science, technology and industry; biotechnology and biodiversity; education; employment, labour and social affairs; entrepreneurship, small and middle-sized enterprises; and local development.

Relations with non-members. In order to ensure its continuing relevance as a hub for dialogue and action on globally significant policy issues, the OECD has developed an active global relations strategy and maintains co-operative relations with many economies outside the OECD. Officials from non-member economies increasingly discuss policy with their counterparts from member countries and conduct peer assessments while sharing each other's policy experiences. In 2007 the OECD launched a process of enhanced engagement with five countries whose engagement in the work of the OECD is particularly important for the fulfilment of the Organisation's mandate to promote policy convergence and global economic development: Brazil, China, India, Indonesia and South Africa. It aims to bring these countries closer to the OECD by engaging them actively in the OECD's analytical and policy development work, while supporting their own reform processes.

Other activities with non-OECD members are grouped around Global Forums in 12 policy areas. Created by Committees as stable, active networks of policy makers in OECD member and non-member economies, as well as other stakeholders, the Global Forums focus on: agriculture, biotechnology, competition, development, education, environment, finance, international investment, the knowledge economy, public governance, taxation and trade. A regional approach provides for targeted co-operation with non-OECD economies in Europe, Asia, Latin America, the Middle East and Northern Africa (MENA), and in Africa more generally, where the OECD supports the objectives of the
New Partnership for Africa's Development (NEPAD) and the initiatives of the African Partnership Forum. The Centre for Cooperation with Non-Members develops the overall architecture of co-operation and general liaison with non-members, while the substantive directorates implement the programmes and activities in each policy area.

Relations with developing countries. Developing countries participate in many of the OECD's above-mentioned activities with non-members. The principal body dealing with issues related to development co-operation is the Development Assistance Committee (DAC). Its 23 members are major aid donors, collectively accounting for over $90 \%$ of total official development assistance (ODA) worldwide amounting to approximately US $\$ 120 \mathrm{bn}$. in 2008 . The DAC largely focuses on how to spend and invest this aid so as to help its partners achieve the Millennium Development Goals and produces analysis and guidance on a range of topics, including aid for trade, aid effectiveness, capacity development, poverty reduction, environment, conflict and fragility, gender equality, good governance, evaluation and aid architecture.

The OECD Development Centre links OECD member countries and developing countries in Africa, Asia and Latin America by helping policy makers in OECD and developing countries find solutions to the challenges of development, poverty alleviation and the curbing of inequality through recommendations designed to promote constructive policy change. Annual publications include the Latin American Economic Outlook and, jointly with the African Development Bank, the African Economic Outlook.

The OECD's policy dialogue is also developing at a regional level, particularly through the work of the Sahel and West Africa Club (SWAC) which acts as an interface between West African actors and OECD member countries. Administratively attached to the OECD, the SWAC is led by a secretariat based in Paris and combines direct field involvement with analyses of West African realities. The SWAC works with regional institutions, governments, business and civil society organizations to promote the regional dimension of development, support the formulation and implementation of joint or intergovernmental policies and thereby contribute to mobilizing and strengthening West African capacities.

Relations with other international organizations. Under a protocol signed at the same time as the OECD Convention, the European Commission takes part in the work of the OECD. EFTA may also send representatives to attend OECD meetings. Formal relations also exist with the Asian Development Bank, Inter-American Development Bank, World Bank, IMF, UNCTAD, WHO and the Parliamentary Assemblies of the Council of Europe and NATO.

Relations with civil society. Consultations with civil society organizations (CSOs) take place across the whole range of the OECD's work. The Business and Industry Advisory Committee to the OECD (BIAC) and the Trade Union Advisory Committee to the OECD (TUAC) have consultative status enabling them to discuss subjects of common interest and be consulted in a particular field by the relevant OECD Committee or its officers. Individual committees are in direct dialogue with CSOs interested in following their areas of work and establish modalities for consultations, and in some exceptional cases CSOs have expert status. Since 2000 the OECD has organized the annual OECD Forum, an international public conference offering business, labour and civil society the opportunity to discuss key issues of the 21st century with government ministers and leaders of international organizations.

Organization. The governing body of the OECD is the Council, comprising representatives of each member country and in which the European Commission participates. It usually meets once a year at the level of government ministers, with a rotating 